\title{
The genealogy of social hatred
}

\author{
ILDIKÓ BARNA* (1)
}

Eötvös Loránd University, Faculty of Social Sciences

\section{ORIGINAL RESEARCH PAPER}

Received: February 14, 2020 - Revised manuscript received: September 15, 2020 - Accepted: October 13, 2020

Published online: October 21, 2021

(C) 2020 The Author(s)

\section{ABSTRACT}

The paper aims at providing an overview of hate crimes through an interdisciplinary lens based not only on theories but also empirical research results. The paper first deals with the central components of hate crimes: prejudice and aggression. Not only the classical social-psychological theories of these phenomena are discussed but also some newer ones. As hate crimes do not occur in a vacuum, the next chapter of the paper deals with the social, political, cultural context and factors that facilitate or impede the occurrence of hate crimes. Community disorganization, urban ecology, racial balance, residential stability, economic conditions, and the role of the media and the internet are discussed in detail. The last chapter of the paper deals with the perpetrators of hate crimes, let them be lonely ones or members of organized hate groups. The paper demonstrates that the investigation of hate crimes can only occur in an interdisciplinary setting that can simultaneously take into account legal, social, cultural, and political factors.

\section{KEYWORDS}

hate crimes, oveniew, theories, research results, interdisciplinary approach

\footnotetext{
*Corresponding author. E-mail: barna.ildiko@tatk.elte.hu
}

The present paper was authored in the framework of the MTA-ELTE Lendület SPECTRA Research Group (Social prerequisites for the effective fight against bias-motivated crimes through criminal law and minority rights protection, contract number: LP2018-9/2018). 


\section{INTRODUCTION}

Many attempts have been made to define hate crimes. Jacob and Potter argue that the amount of hate crime and the appropriate response depends on how hate crime is defined and conceptualized. ${ }^{1}$ Many definitions emphasize prejudice, stating that hate crime is criminal conduct motivated by prejudice'. ${ }^{2}$ However, Chakraborti and Garland emphasize that 'the pivotal characteristic of a hate crime is the group affiliation of the victim, and not the presence of hate on the part of the perpetrator'. ${ }^{3}$ There have been definitions that emphasized 'the imbalance of power between the perpetrator and the victim'. ${ }^{4}$ Besides defining what hate crime is, its social, cultural, and political context also needs to be considered, as '[i]t does not occur in a cultural or social vacuum'.

\section{PREUUDICE AND AGGRESSION}

Prejudice and aggression are essential parts of hate crimes, and this section deals with these concepts. According to Allport, prejudice is 'an antipathy based upon a faulty and inflexible generalization'. ${ }^{6}$ Taking into account the connection prejudice has to social groups, 'prejudice is an attitude directed toward people because they are members of a specific social group'. This is in line with some of the definitions of hate crime mentioned above that emphasize the group affiliation of the victim.

Allport differentiated between certain degrees of negative actions deriving from prejudice, starting from the least 'energetic' to the most. Two are important for this work as they are forms of hate crime: physical attack and extermination. This paper deal with hate crimes but it is essential to note that as Allport states, violence is always preceded by milder manifestations of prejudice, such as antilocution, avoidance, or discrimination. According to Allport, there are certain prerequisites of physical violence. These are a long period of categorical prejudgment; a long period of verbal complaint against the victimized minority; growing discrimination; an ingroup that long time suffered from economic deprivation, irritation due to political developments; people losing their inhibitions, organized movements; formal and informal social organization from which the individuals derive courage and support, some triggering incident, event. ${ }^{8}$

\subsection{Personality-based theories}

After the Holocaust, researchers aimed to understand the factors which make an individual especially prone to prejudice. The first attempts were rooted in Freudian psychoanalysis and

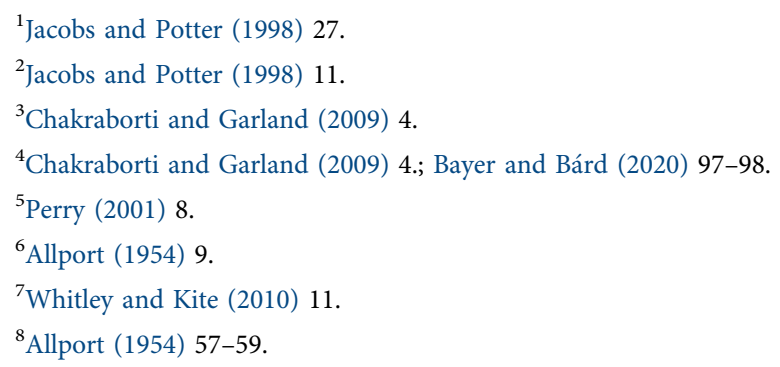


concentrated on personal traits. The most influential one was the work of Adorno and his colleagues. ${ }^{9}$ They proposed the existence of the authoritarian personality said to be especially susceptible to prejudice. Five of the nine characteristics of the authoritarian personality were connected to prejudice: conventionalism, authoritarian submission, authoritarian aggression, stereotypy, and projectivity. ${ }^{10}$ It was argued that autocratic, rigid, and punitive child-rearing practices and the constant punishment of any non-conform behavior were the causes of this personality syndrome. According to the theory, authoritarian personalities follow social conventions. They perceive these conventions accepted and valued by the majority, and any attempt, even violent ones, to defend these norms seems legitimate and acceptable to them. ${ }^{11}$ The theory of the authoritarian personality emphasized the internal psychodynamic conflict between 'a highly restrictive superego and the instinctual drives of the id'. ${ }^{12}$ According to this model, many of the persons' impulses and feelings are unacceptable for the superego, which plays a critical and moral role in a person's psyche. This internal psychodynamic conflict causes guilt, frustration, and aggressive feelings, and the way to reduce these feelings is to find suitable scapegoats.

Contrary to stressing internal psychodynamic conflicts, the frustration-aggression hypothesis ${ }^{13}$ emphasized external frustration arising when people are blocked in achieving their goals. Although the original formulation of the theory stated that frustration always leads to aggression and the prerequisite of aggression is frustration, later researchers ${ }^{14}$ argued that aggression could occur without frustration, and frustration can lead to other responses, aggression being one of them. Another difference between the theory of the authoritarian personality and the frustration-aggression hypothesis is that the former considered prejudice as a pathological characteristic whilst the latter as a product of normal functioning of the human mind.

Both the psychodynamic and the frustration-aggression approach 'believed that aggression would be displaced onto an innocent target if the true source of frustration was powerful and therefore likely to retaliate'. ${ }^{15}$ In this way, both theories 'invoke the notions of displaced aggression (directing aggressive impulses toward an innocent target) and projection (attributing negative characteristics and blame to targets to justify aggressing against them), ${ }^{16}$ both are closely connected to scapegoating. However, as Allport ${ }^{17}$ identified, the two approaches deal with different types of projection, the first being due to internal, while the second to external sources. Allport ${ }^{18}$ dubbed the two different types of projection: direct, in the case of the Freudian approach and complementary projection in the case of the frustration-aggression approach. In the first case, 'the individual's own unacceptable impulses are projected onto others, allowing

\footnotetext{
${ }^{9}$ Adorno et al. (1950).

${ }^{10}$ Whitley and Kite (2010) 234.

${ }^{11}$ Turpin-Petrosino (2015).

${ }^{12}$ Glick (2005) 245.

${ }^{13}$ Dollard et al. (1939).

${ }^{14}$ Allport (1954); Bandura (1973); Berkowitz (1962).

${ }^{15}$ Glick (2005) 245-46.

${ }^{16}$ Glick (2005) 246.

${ }^{17}$ Allport (1954).

${ }^{18}$ Allport (1954).
} 
people to deny their own faults', ${ }^{19}$ while in the second, projection is used to 'explain feelings (of which they are consciously aware) by projecting complementary, causal traits onto others' ${ }^{20}$

The theory of social learning has described another way of learning aggression. The main idea behind this theory, developed by Bandura, ${ }^{21}$ is that important forms of social behavior are mainly acquired by observing and imitating others. Learning is a cognitive process that takes place in a social context, and the most important parts of this process are the rewards (social approval) and punishments (social disapproval), which shape behavior. The focus of Bandura's research was the learning process of aggressive behavior, and in this sense, it is particularly related to the topic of hate crimes. In his most famous experiment, the Bobo doll experiment, Badura and his colleagues found that those children who observed an adult aggressively playing with the doll were more likely to imitate this behavior. ${ }^{22}$ Based on social learning theory, the utmost importance of childhood in the learning of intergroup bias can be argued. ${ }^{23}$ It can also be expected that those who come from families and sociocultural environments where prejudiced thinking is accepted or even rewarded are more likely to be prejudiced themselves, which in extreme cases can lead to committing hate crimes. ${ }^{24}$ The most important scenes of social learning are the family, educational institutions, and other institutions or communities with which the child is in contact. Research on social learning has focused primarily on childhood, social learning continues into adulthood, and the social environment continues to influence behavior.

There are two more personality theories of prejudice, closely connected to the authoritarian personality, that need to be mentioned: dogmatism proposed by Rokeach and right-wing authoritarianism proposed by Altemeyer. While Adorno's theory was closely connected to rightwing views, Rokeach aimed at measuring authoritarianism, whether left or right, and focused on a more general cognitive style. 'Rokeach argue[d] for the existence of a more generalized syndrome of intolerance, called dogmatism or closed-mindedness. It is characterized by isolation of contradictory belief systems from one another, resistance to belief change in the light of new information, and appeals to authority to justify the correctness of existing beliefs'. ${ }^{25}$

Right-wing authoritarianism (RWA) described authoritarianism as a collection of attitudes rather than a personality type, the views of Adorno and colleagues. According to Altemeyer, right-wing authoritarian people have a high degree of willingness to submit to authorities (authoritarian submission). They adhere to social norms and conventions (conventionalism). However, they are hostile and punitive toward people who do not (authoritarian aggression). ${ }^{26}$ Research showed that people high in RWA tend to be prejudiced against a wide variety of groups.

There is another personality trait that is closely connected to prejudice: the social dominance orientation (SDO). Sidanius and Pratto state that 'SDO is defined as the degree to which

\footnotetext{
${ }^{19}$ Dovidio, Glick, and Rudman (2005) 246.

${ }^{20}$ Glick (2005) 246.

${ }^{21}$ Bandura (1977).

${ }^{22}$ Bandura, Ross, and Ross (1961).

${ }^{23}$ Over and McCall (2018).

${ }^{24}$ Mills et al. (2019); Turpin-Petrosino (2015) 90-91.

${ }^{25}$ Hogg and Vaughan (2011) 389.

${ }^{26}$ Altemeyer (1981; 1998).
} 
individuals desire and support group-based hierarchy and the domination of 'inferior' groups by 'superior' groups'. 27

\subsection{Group-based theories}

Realistic group conflict theory was the first intergroup theory of prejudice where people are motivated by a desire to maximize rewards in life. To achieve this goal, they form groups to corporate with others who share the same goal. 'However, because different groups are frequently in pursuit of those same resources, they end up competing with one another for those rewards. According to realistic conflict theory, this competition leads to conflict between groups; one result of this conflict is a disliking for, or prejudice against, members of competing groups. $^{28}$

Henri Tajfel accepting that competition for resources leads to intergroup conflict, argued that group membership in itself could determine behavior and proposed social identity theory. Henri Tajfel defined social identity as 'The individual's knowledge that he belongs to certain social groups with some emotional and value significance to him of the group membership. ${ }^{29}$ The individual's social identity has a significant impact on how the individual sees themselves and others, which basically makes the difference between the in-group (same group as self) and the outgroup (different group to self). People with high RWA are especially inclined to 'organize their worldview in terms of in-groups and outgroups.' ${ }^{30}$ 'People perceive members of the outgroup as more similar to each other than they actually are while seeing members of the in-group as distinct individuals. As a result, people believe differences between the in-group and the outgroup to be greater than they really are. ${ }^{31}$

Social identity theory is based on social categorization, which transforms individuals into groups and gives way to the depersonalization of outgroup members. It is closely connected to stereotyping as it is the depersonalized perception of outgroup members. Social categorization operates together with social comparison; when comparisons are made between oneself and others and, more importantly, between oneself as in-group members with others as outgroup members. During social comparison, in-group are treated positively while the outgroup is downgraded. This mechanism is called intergroup bias.

Researchers proved two hypotheses to explain intergroup bias: the categorization-competition hypothesis and the self-esteem hypothesis. The first holds that 'categorizing oneself and others into an in-group and an outgroup is sufficient to generate intergroup competition, ${ }^{32}$ as social categorization arouses feelings of competition which leads to the in-group favoritism effect. 'Social identity theory proposes that people are motivated to achieve and maintain positive social identities. ${ }^{33}$ The self-esteem hypothesis states that 'successful intergroup bias

\footnotetext{
${ }^{27}$ Sidanius and Pratto (1999) 48.

${ }^{28}$ Whitley and Kite (2010) 326.

${ }^{29}$ Tajfel (1974) 72.

${ }^{30}$ Whitley and Kite (2010) 237.

${ }^{31}$ Whitley and Kite (2010) 331.

${ }^{32}$ Whitley and Kite (2010) 331.

${ }^{33}$ Whitley and Kite (2010) 332.
} 
creates or protects relatively high in-group status, thereby providing a positive social identity for in-group members and satisfying their need for positive self-esteem'. ${ }^{34}$

In the last two decades, one of the most influential explanations of prejudices was the integrated threat theory. This theory dealt with four components of threat: realistic threat, symbolic threat, intergroup anxiety, and negative stereotypes. ${ }^{35}$ A modified version of the theory, intergroup threat theory, kept only the first two. ${ }^{36}$ Realistic threats, a concept closely connected to realistic threat theory, are those that threaten the very existence of the in-group, like its wellbeing, physical safety, economic and political power. The symbolic threat arises from the perceived difference between the in- and the outgroup's attitudes, norms, and moral. In this case, members of the in-group feel that the outgroup threatens their values, worldview, and way of life.

\section{THE CONTEXT OF HATE CRIMES}

This part of the paper deals with the social, political, cultural context, and factors that facilitate or impede the occurrence of hate crimes.

\subsection{Community disorganization}

Social disorganization theory deals with the relationship between neighborhood structure and crime. 'Social disorganization refers to the inability of a community to realize common goals and solve chronic problems'. ${ }^{37}$ The classical social disorganization theory dealt with three indicators of social disorganization: poverty, ethnic heterogeneity, and residential turnover. However, poverty was later replaced by 'concentrated disadvantage' as the previous measure was insufficient to capture an important aspect, which is the aggregation of disadvantages, i.e., poverty, family disruption, joblessness, bad schools, few conventional role models. ${ }^{38}$ Although, at first, social disorganization theory focused on structural variables, Kubrin and Weitzer ${ }^{39}$ emphasized the importance of other variables that can mediate the relationship between structural characteristics of neighborhoods and crime: informal control, social ties, social capital, neighborhood culture, and collective efficacy. The latter means 'the shared sense among residents that others will intervene to manage and control problems that emerge in the neighborhood'. ${ }^{40}$

The original form of social disorganization theory dealt with ordinary crime. Therefore, the question arose whether the theory also applies to hate crimes. Grattet, ${ }^{41}$ using hate crime reports by the Sacramento Police Department and US Census data, found that in socially disorganized neighborhoods, there is a greater chance for hate crimes to occur. However, it is important to note that Grattet used only structural variables to measure disorganization. Gladfelter, Lantz,

\footnotetext{
${ }^{34}$ Hewstone, Rubin and Willis (2002) 580.

${ }^{35}$ Stephan and Stephan (1996).

${ }^{36}$ Stephan and Renfo (2002).

${ }^{37}$ Kubrin and Weitzer (2003) 374.

${ }^{38}$ Grattet (2009) 135.

${ }^{39}$ Kubrin and Weitzer (2003).

${ }^{40}$ Grattet (2009) 134.

${ }^{41}$ Grattet (2009).
} 
and Ruback ${ }^{42}$ used hate crime data collected by the Pennsylvania Human Relations Commission for the period between 2000 and 2011. Census and survey data were also used. They tested the effect different indicators of social disorganization have and found that social disorganization can explain rates of hate crimes. Moreover, they drew more far-reaching conclusions. Based on their results, they argued that traditional criminology theory could also be used for hate crimes. However, they pointed out that hate crimes against different racial groups should be treated separately, as their relationships to various social disorganization indicators varied significantly.

\subsection{Urban ecology, racial balance, and residential stability}

There are competing hypotheses about the correlation between racial balance and hate crimes. '[T] he power-threat hypothesis ${ }^{43}$ holds that white intolerance is greatest where the size of the nonwhite population presents a challenge to the economic interests and dominant social and political position of whites'. ${ }^{44}$ On the contrary, the power-differential hypothesis, as well as the defended neighborhood hypothesis, suggest that acts of racial hatred will be more frequent in areas where members of the majority group are in numerical superiority. The defended neighborhood hypothesis can be closely connected to the previously mentioned realistic group threat theory as with the appearance of a member of the outgroup, hate crime perpetrators may perceive that the values and norms of the majority group have been endangered.

The power-threat and the power-differential theses differ in the assessment of the effect of demographic change. The power-differential hypothesis suggests that the growth of the minority groups increases the capacity of minority-group members to protect themselves. On the contrary, the defended neighborhood thesis argues that demographic change 'represents the catalyst for action among those who seek to preserve racial homogeneity'. ${ }^{45}$

Green, Strolovitch, and Wong ${ }^{46}$ investigated the relationship of demographic and macroeconomic variables with racially motivated anti-minority crimes in New York City between 1987 and 1995. Their results supported the defended neighborhood thesis. Moreover, Grattet found that 'neighborhood defense' affects even when controlling for some of the key measures of social disorganization. ${ }^{47}$

Lyons $^{48}$ examined the effect community's structural conditions, racial, and ethnic demographics have on hate crimes. He analyzed police records, census, and survey data from Chicago and found different patterns in the case of anti-black and anti-white crime motivated by racial hatred. In line with the defended neighborhood perspective, he found that anti-black hate crimes are more frequent where whites comprise larger proportions of the community, especially in traditionally homogeneous white communities with a recent in-migration of blacks. His results indicated that 'the influx of black newcomers matters only in white communities whose

\footnotetext{
${ }^{42}$ Gladfelter, Lantz and Ruback (2015).

${ }^{43}$ Blalock (1976); Tolnay, Beck and Massey (1989); both cited by Green, Strolovitch and Wong (1998).

${ }^{44}$ Green, Strolovitch and Wong (1998) 373.

${ }^{45}$ Green, Strolovitch and Wong (1998) 376.

${ }^{46}$ Green, Strolovitch and Wong (1998).

${ }^{47}$ Gratett (2009) 147.

${ }^{48}$ Lyons $(2007,2008)$.
} 
residents express a strong sense of community attachment'. ${ }^{49}$ Moreover, it is more likely 'in relatively organized communities with higher levels of informal social control, and especially in internally organized white communities $[\ldots]^{50}$. Anti-black hate crimes were also more frequent in neighborhoods with higher social status. As these internally organized, relatively well-off communities often characterized by high social capital tend to be more concerned about safety and public order. The content of stereotypes and prejudices about blacks is often connected to disorder, violence, and poverty. Therefore the presence of blacks can be perceived 'as a sign of decline and impending disorder' as well as a 'threat of racial invasion'51. This sense of threat can be well connected to realistic threat as defined by the integrated threat theory.

On the contrary to anti-black hate crimes, anti-white ones 'appear most common in relatively heterogeneous communities where blacks and whites comprise sizeable, more equitable proportions of the population' 52 and 'somewhat more likely in disadvantaged communities, especially those with higher levels of residential instability'. ${ }^{53}$

Stacey, Carbone-López, and Rosenfeld ${ }^{54}$ examined the effect of Hispanic immigration to the United States on hate crimes against Hispanics. They have found that at the state level, with the increase of Hispanic immigration, the number of hate crimes against them has also increased. However, when the relative number of Hispanics was examined, the opposite effect was observed. This research also shows that when the effect of the increase in the number of a given minority is scrutinized, several factors need to be considered.

The effect of the compositional change was studied in Germany by Entorf and Lange. ${ }^{55}$ In their research, they scrutinized the relationship between the large number of asylum seekers arriving in Germany during 2014 and 2015 and the number of hate crimes. Results showed that it was not the number of asylum seekers itself but the rapid compositional change that had an impact on the number of hate crimes. They found that the increase in the number of asylum seekers resulted in an increased number of hate crimes in areas where previously, the share of foreign-born inhabitants was low, where such crimes have been present even before, and areas under economic strain.

\subsection{Economic conditions}

The impact of economic conditions on hate crimes in itself has been studied at both the macro and micro levels. The first macro-level study was carried out by Hovland and Sears, ${ }^{56}$ who reported a strong relationship between economic indicators and Black lynching. In their seminal work, they summarized their results as follows: '[d]uring periods of depression the number of

\footnotetext{
${ }^{49}$ Lyons (2007) 378.

${ }^{50}$ Lyons (2007) 847.

${ }^{51}$ Lyons (2007) 847.

${ }^{52}$ Lyons (2007) 379.

${ }^{53}$ Lyons (2007) 848.

${ }^{54}$ Stacey and Carbone-López (2011).

${ }^{55}$ Entorf and Lange (2019).

${ }^{56}$ Hovland and Sears (1940).
} 
lynchings is high; during prosperity the number of lynchings declines' ${ }^{57}$ Later, Hepworth and West $^{58}$ reanalyzed the data of Hovland and Sears using modern statistical tools. They also found a significant positive correlation between economic conditions and hate crime, although much weaker than in the original research. At the macro level, several further studies have found that various macroeconomic factors, such as rising unemployment, declining market wage rates, increase hateful activity. ${ }^{59}$

However, some researchers have warned that the relationship between these factors is far from clear. For example, Green, Strolovitch, and Wong ${ }^{60}$ found no significant relationship between economic conditions and hate crimes against gays and lesbians.

On the micro level, the role of the person's or group's economic situation in the formation of prejudices has already been mentioned. According to realistic group conflict theory, the competition over finite resources leads to intergroup conflicts. This theory also suggests that the real or perceived deterioration in a group's relative status can also result in increased hostility. The concept of realistic threat coming from intergroup threat theory is also closely connected to economic conditions as it arises when the in-group perceives that the outgroup threatens its economic position or its access to scarce goods.

Perry's line of thought is also related to the previously mentioned theories. However, she examined the relationship between the economic situation and hate crimes from the perspective of the societies' power structure. Her analysis assumes that many minority groups have traditionally been marginalized in society. She believes that as more and more members of these groups have moved up on the economic ladder, so has the prejudice against them. It follows from Perry's line of reasoning that this may be most characteristic of those strata of society where the members of these minority groups are 'perceived as unfair and undeserving competitors, and takers of "white jobs". 61

The assumption logically follows from the above that economic factors may have an effect only in the case of those groups where the possible presence of realistic threat is sound. This thought was the exact starting point of the research by Butz and Yogeeswaran. ${ }^{62}$ In their experimental study, they found that the economic threat increased prejudices against Asian Americans but did not increase that against Black Americans. To explain these results, the researchers argued that while the group of Asian Americans is 'an ethnic group whose stereotype implies a threat to scarce employment opportunities,' the group of Black Americans is 'an ethnic group whose stereotype does not imply a threat to economic resources'. ${ }^{63}$ Since Butz and Yogeeswaran used experiments, they couldn't analyze the effect of economic threat has on hate crimes.

\footnotetext{
${ }^{57}$ Hovland and Sears (1940) 310.

${ }^{58}$ Hepworth and West (1988).

${ }^{59}$ Falk, Kuhn and Zweimüller (2011); Medoff (1999).

${ }^{60}$ Green, Strolovitch and Wong (1998).

${ }^{61}$ Perry (2001) 74.

${ }^{62}$ Butz and Yogeeswaran (2011).

${ }^{63}$ Butz and Yogeeswaran (2011) 26.
} 


\subsection{The role of the media and the internet}

The possible role of the media in the incitement of hatred is well-known. However, with the emergence of the internet in general and social media in particular, its impact became overwhelming and globalized. Much of the literature on the internet and social media deals with hate speech. Although action is always preceded by words, discussing them is beyond the scope of this paper. However, some researches deal specifically with the relationship between social media and hate crimes. ${ }^{64}$ It is especially interesting when the role of the media and the internet is analyzed in connection to propaganda. In their research, Edwards and Rushin ${ }^{65}$ addressed the so-called Trump Effect, a phenomenon dubbed by media commentators. They examined the impact of the rhetoric used by Donald Trump in the presidential campaign, as well as his subsequent election, on the number of hate crimes. Based on their analyzes, they were able to confirm the Trump Effect. In the case of Italian municipalities, Romarri ${ }^{66}$ examined the effect of having a far-right mayor on the likelihood of hate crimes. His results showed that a far-right mayor significantly increases the annual probability of hate crime. He also showed that this effect prevails partly through the media.

3.4.1. Moral panic. The role of the media and the internet is often framed with the concept of moral panic. Stanley Cohen, in his seminal work on moral panic, defined the phenomenon as 'a condition, episode, person or groups of persons emerges to become defined as a threat to societal values and interests'. ${ }^{67}$ Later, Goode and Ben-Yehuda identified five crucial elements of moral panic. In case of a moral panic, a substantial part of the society is concerned over the behavior of and there is hostility against the given group. It is also important that there is a widespread social consensus about it. Exaggerated fear is also present, meaning that there is a disproportion between the perception and the actual threat, danger, and damage caused by the given group. Finally, the fifth element of moral panic is its volatility. ${ }^{68}$

Researchers have already emphasized the prominent role of the mass media in the development and maintenance of moral panic since the origin of moral panic theory. The media was thought to have a primary role in 'setting the agenda,' 'transmitting the images,' and 'breaking the silence, making the claim'. ${ }^{69}$ Traditional print media has been analyzed, ${ }^{70}$ but with the emergence of the internet has taken over the main role of whipping up and maintaining moral panic creating 'cyber moral panic'.

Although it is hard to prove the direct causal link between moral panic and hate crimes, various researchers hypothesized such a relationship. It is hard to believe, for example, that the spread of hate against Muslims after 9/11 did not have a causal relationship with the 1,600

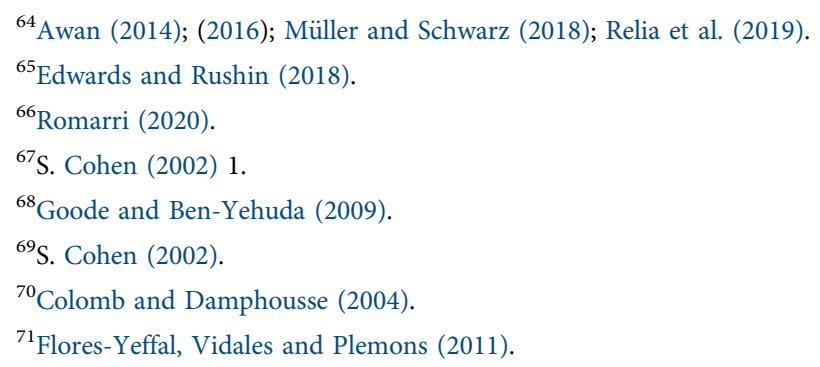


percent increase of hate crimes committed against Arabs and Muslims in 2000 and $2001 .^{72}$ Moral panics and their assumed connection to hate crimes have been analyzed in the case of various groups, for example, Muslims, especially after $9 / 11,{ }^{73}$ and Latinos. ${ }^{74}$

\subsection{The absence of punishment}

The social context of hate crimes also includes the fact whether the perpetrators of hate crimes are generally held accountable in a given society or that crimes for several reasons remain unpunished. The absence of punishment has different consequences in the case of hate crimes than other crimes. In the case of hate crimes, this can not only encourage the perpetrators to commit these crimes but it 'signals that the victim and even the whole group to which the victim belongs deserves this fate'. ${ }^{75}$

This line of thought is based on the 'belief in a just world' concept. 'The just world belief implies that individuals generally believe that the world is a fair place to live in, and that justice is being done such that people get what they deserve. When an individual becomes the victim of a hate crime on the sole basis of their group identity, observers may start restoring their belief in a just world by derogating the victim. More importantly, the absence of punishment signals that the violence not only against one individual but against a whole group is justified. ${ }^{76}$, Sullivan and her colleagues experimentally proved that the strategy of individuals to preserve their belief in the just world leads not only to the derogation of individual victims but also of their groups ${ }^{77}$.

\section{THE PERPETRATORS OF HATE CRIMES}

There are no overall characteristics of hate crime offenders. Some research found that perpetrators of hate crimes were mainly young white males with low educational attainment, coming from deprived, disrupted, dysfunctional families where violence was the primary way of solving problems. $^{78}$ Other research concentrated on the personality of hate crime offenders by describing them as being socially isolated with low self-esteem. ${ }^{79}$

\subsection{Motivations for committing hate crimes}

McDevitt, Levin, and Bennett ${ }^{80}$ scrutinized the motivation for hate crime offenders. They examined 169 cases between 1991 and 1992 of the Community Disorders Unit of the Boston Police

\footnotetext{
${ }^{72}$ Alsultany (2013) 161.

${ }^{73}$ Rothe and Muzzatti (2004); Poynting (2006); Welch (2006); Frost (2008); Shafir, Meade and Aceves (2013); Morgan and Poynting (2016).

${ }^{74}$ Flores-Yeffal, Vidales and Plemons (2011).

${ }^{75}$ Fischer et al. (2018) 8.

${ }^{76}$ Fischer et al. (2018) 7.

${ }^{77}$ Sullivan et al. (2016).

${ }^{78}$ Dunbar, Quinones and Crevecoeur (2005), Ray, Smith and Wastell (2004).

${ }^{79}$ Anderson, Dyson and Brooks (2002).

${ }^{80} \mathrm{McD}$ evitt, Levin and Bennett (2002).
} 
Department. They found that the most common motivation was thrill or excitement of the act. In these cases, the offenders, often youths, told the police that they were just bored and looking for some fun. This motivation also includes the effect of the peer group. However, Franklin ${ }^{81}$ treated this motivation separately. In her typology, this motivation reflects the offender's desire to feel closer to their friends, to live up to their friends' expectations, or to be accepted by peers.

Defense can also be a motivation for hate crimes. It includes when offenders want to protect their territory, such as their neighborhood, from outsiders or intruders ${ }^{82}$ or when assailants see their hate crime acts as legitimate self-defense. ${ }^{83}$ Another motivation can be when a group feels that its relative status is in danger. ${ }^{84}$ However, the defense may also apply to more symbolic objects, such as when perpetrators perceive a threat to their way of living. Hate crimes motivated by defense are based on anger and fear and are mostly committed by single persons. ${ }^{85}$ These different types of defenses are in line with realistic group theory, as well as with the two main concepts of integrated threat theory: realistic and symbolic threat, described above.

The third motivation McDevitt and his colleagues ${ }^{86}$ distinguished was retaliation. This type of retaliatory hate crime can be the consequence of an original hate crime act. However, rumors about such an action can also trigger retaliation.

In addition, McDevitt, Levin, and Bennett ${ }^{87}$ identified the mission hate crimes committed out of bigotry. However, according to their sample, this motivation proved to be very rare.

The first three motivations, thrill, defense, and retaliation, can be connected to routine activities theory (RAT) ${ }^{88}$ The theory, proposed by Cohen and Felson, ${ }^{89}$ argued that three critical elements of crime must co-occur: 'likely offenders,' 'suitable targets,' and 'the absence of capable guardians against crime.' The theory's name suggests that everyday routines and activities create opportunities for crime. The authors applied their theory to what they called direct-contact predatory violations. They defined predatory violations as illegal acts in which someone definitely and intentionally takes or damages the person or property of another. ${ }^{90}$ At the same time, predatory referred to the 'direct physical contact between at least one offender and at least one person or object which that offender attempts to take or damage. ${ }^{91}$ According to this definition, hate crimes can be considered as one type of these criminal acts.

Turpin-Petrosino ${ }^{92}$ applied RAT for hate crimes motivated by thrill, defense, or retaliation. In the case of the first one, suitable victims are often found connected to their routine activity,

\footnotetext{
${ }^{81}$ However, Franklin (2000).

${ }^{82}$ McDevitt, Levin and Bennett (2002).

${ }^{83}$ Franklin (2000).

${ }^{84}$ Bobo (1983); Butz and Yogeeswaran (2011); Perry (2001).

${ }^{85}$ Fischer et al. (2018).

${ }^{86} \mathrm{McD}$ evitt, Levin and Bennett (2002).

${ }^{87}$ McDevitt, Levin and Bennett (2002).

${ }^{88}$ Turpin-Petrosino (2015) 84-87.

${ }^{89}$ Cohen and Felson (1979).

${ }^{90}$ Cohen and Felson (1979) 589.

${ }^{91}$ Cohen and Felson (1979) 589.

${ }^{92}$ Turpin-Petrosino (2015).
} 
e.g., LGBTQ community members in gay-friendly establishments, or African Americans or Latinos in segregated residential areas. In the classic examples of defense-motivated hate crimes involving 'move-in violence,' the newly available suitable targets are identified and attacked by the majority. In the case of retaliation, the real or supposed actions against the in-group 'create' the offenders and the targets. 'Likely offenders' and the 'suitable targets' have been dealt with, but what is more interesting in the case of hate crimes is 'the absence of capable guardians.' There can be concrete forms: the questionable support offered for the victimized community by local authorities, law enforcement bodies, or simply by members of the majority group. However, Turpin-Petrosino mentions a much more important form, which she calls 'symbolic absence of guardianship' implied by a cultural mindset.

\subsection{Organized hate groups}

According to the definition of the Southern Poverty Law Center, 'a hate group (which is comprised of at least two or more individuals) has beliefs and practices that attack or malign an entire class of people, typically for their immutable characteristics'. ${ }^{93}$

Examining organized hate groups and their members' motivation to join them is an important aspect of understanding hate crimes, especially because hate crimes committed by these groups are often more severe. ${ }^{94}$ At the same time, it has to be stated that most hate crimes are committed not by these groups. ${ }^{95}$ Moreover, Ryan and Leeson ${ }^{96}$ found that in the United States, hate groups are hardy associated with hate crimes. ${ }^{97}$ However, one of the reasons for this may be the fact mentioned above that the proportion of hate crimes committed by hate groups is relatively low.

There is another important aspect of analysis about hate groups, namely the motivation of some, mostly young, people to join such groups. According to Woold and Hulsizer, '[t]he reasons behind individual's decisions to join groups grounded in enmity are complex but rooted in an interaction of potential personality and situational factors' ${ }^{98}$ The potential personality attributes go back to the personality-based theories that were dealt with at the beginning of this paper. Besides the different types of personalities, it should be emphasized that the process of social learning, which is especially important in the case of hate groups since those who join such groups get a reward for their hatred, which reinforces their prejudices. Not only personality traits but the desire for belonging to a group can promote joining a hate group. It has been seen, based on social identity theory, how group membership can enhance one's self-esteem.

\section{CONCLUSION}

The paper addressed three aspects of hate crimes: first, the social-psychological background of prejudice and aggression, which are essential elements of hate crime. Second, the factors that

\footnotetext{
${ }^{93}$ Turpin-Petrosino (2015).

${ }^{94}$ Dunbar, Quinones and Crevecoeur (2005).

${ }^{95}$ Jacobs and Potter (1997) 19.

${ }^{96}$ Ryan and Leeson (2011).

${ }^{97}$ Ryan and Leeson (2011).

${ }^{98}$ Woolf and Hulsizer (2004) 46.
} 
increase the incidence of hate crime were discussed. These are important as hate crimes do not occur in a social, political, cultural vacuum. Therefore, understanding the context of hate crimes is of utmost importance. And finally, the paper dealt with the perpetrators of hate crimes, whether they had committed the offense in their individual capacity or as members of hate groups.

We dealt with various theories explaining prejudice. Now, we would like to highlight one of them: the intergroup threat theory. The theory, as discussed earlier, deals with realistic and symbolic threat. However, this theory has proved to be an adequate interpretive framework not only in the explanation of prejudice but also in the case of other factors behind hate crime, such as neighborhood composition or economic conditions. Moreover, it also helps us to interpret the various motivation of hate crimes.

The paper also demonstrated that the investigation of hate crimes can only take place in an interdisciplinary setting that can simultaneously take into account legal, social, cultural, and political factors.

\section{REFERENCES}

Adorno, T. W., Frenkel-Brunswik, E., Levinson, D. J. and Sanford, R. N., The authoritarian personality (Harpers 1950).

Allport, G. W., The Nature of Prejudice (Addison - Wesley 1954).

Alsultany, E., 'Arabs and Muslims in the Media after 9/11: Representational Strategies for a 'Postrace' Era.' (2013) 65 American Quarterly 161-69.

Altemeyer, B., Right-Wing Authoritarianism (University of Manitoba Press 1981).

Altemeyer, B., 'The Other 'Authoritarian Personality." in Mark P. Zanna (ed), Advances in Experimental Social Psychology (volume 30, Academic Press 1998), 47-92.

Anderson, J. F., Dyson, L. and Brooks, W., 'Preventing Hate Crime and Profiling Hate Crime Offenders.' (2002) 26 Western Journal of Black Studies 140-48.

Awan, I., 'Islamophobia and Twitter: A Typology of Online Hate Against Muslims on Social Media.' (2014) 6 Policy \& Internet 133-50.

Awan, I., 'Islamophobia on Social Media: A Qualitative Analysis of the Facebook's Walls of Hate.' (2016) 10 International Journal of Cyber Criminology 1-20.

Bandura, A., Aggression: A Social Learning Analysis (Prentice-Hall 1973).

Bandura, A., Social Learning Theory (Prentice-Hall 1977).

Bandura, A., Ross, D. and Ross, S. A., 'Transmission of Aggression Through Imitation of Aggressive Models.' (1961) 63 Journal of Abnormal and Social Psychology 575-82.

Bayer, J. and Bárd, P., Hate Speech and Hate Crime in the EU and the Evaluation of Online Content Regulation Approaches (European Parliament, 2020).

Berkowitz, L., Aggression: A Social Psychological Analysis (McGraw-Hill 1962).

Blalock, H. M., 1967. In: Toward a Theory of Minority Group Relations. Willey.

Bobo, L., 'Whites' Opposition to Busing: Symbolic Racism or Realistic Group Conflict?' (1983) 45 Journal of Personality and Social Psychology 1196-1210.

Butz, D. A. and Yogeeswaran, K., 'A New Threat in the Air: Macroeconomic Threat Increases Prejudice against Asian Americans.' (2011) 47 Journal of Experimental Social Psychology 22-27. 
Chakraborti, N., and Garland, J., Hate Crime: Impact, Causes and Responses (SAGE 2009).

Cohen, S., Folk Devils and Moral Panics: The Creation of the Mods and Rockers (Psychology Press 2002).

Cohen, L. E. and Felson, M. 'Social Change and Crime Rate Trends: A Routine Activity Approach.' (1979) 44 American Sociological Review 588-608.

Colomb, W. and Damphousse, K., 'Examination of Newspaper Coverage of Hate Crimes: A Moral Panic Perspective.' (2004) 28 American Journal of Criminal Justice 147-63.

Dollard, J., Miller, Neal E. Doob, L. W., Mowrer, O. H. and Sears, R. R., Frustration and Aggression (Yale University Press 1939).

Dovidio, John F., Glick, P. and Rudman, L. A., On the Nature of Prejudice. Fifty Years After Allport (Blackwell Publishing 2005).

Dunbar, E., Quinones, J. and Crevecoeur, D. A., 'Assessment of Hate Crime Offenders: The Role of Bias Intent in Examining Violence Risk.' (2005) 5 Journal of Forensic Psychology Practice 1-19.

Edwards, G. S. and Rushin, S., 'The Effect of President Trump's Election on Hate Crimes.' (January 14, 2018) accessed 12 August 2020.

Entorf, H. and Lange, M., 'Refugees Welcome? Understanding the Regional Heterogeneity of AntiForeigner Hate Crimes in Germany' (January 30, 2019). ZEW - Centre for European Economic Research Discussion Paper No. 19-005.

Falk, A., Kuhn, A. and Zweimüller, J., 'Unemployment and Right-Wing Extremist Crime.' (2011) 113 The Scandinavian Journal of Economics 260-85.

Fischer, A., Halperin, E., Canetti, D. and Jasini, A., 'Why We Hate.' (2018) 10 Emotion Review 309-20.

Flores-Yeffal, N. Y., Vidales, G. and Plemons, A., 'The Latino Cyber-Moral Panic Process in the United States.' (2011) 14 Information, Communication \& Society 568-89.

Franklin, K., 'Antigay Behaviors Among Young Adults: Prevalence, Patterns, and Motivators in a Noncriminal Population.' (2000) 15 Journal of Interpersonal Violence 339-62.

Frost, D., 'Islamophobia: Examining Causal Links Between the Media and 'Race Hate' from 'Below." (2008) 28 International Journal of Sociology and Social Policy 564-78.

Gladfelter, A. S., Lantz, B. and Ruback, R. B., 'The Complexity of Hate Crime and Bias Activity: Variation Across Contexts and Types of Bias.' (2015) 34 Justice Quarterly 55-83.

Glick, P., 'Choice of Scapegoats.' in Dovidio, J. F., Glick, P. and Rudman, L. A. (eds), On the Nature of Prejudice. Fifty Years After Allport (Blackwell Publishing 2005) 244-61.

Goode, E. and Ben-Yehuda, N., Moral Panics: The Social Construction of Deviance (Wiley-Blackwell 2009). Grattet, R., 'The Urban Ecology of Bias Crime: A Study of Disorganized and Defended Neighborhoods.'

(2009) 56 Social Problems 132-50.

Green, D. P., Strolovitch, D. Z. and Wong, J. S., 'Defended Neighborhoods, Integration, and Racially Motivated Crime.' (1998) 104 American Journal of Sociology 372-403.

Hepworth, J. T. and West, S. G., 'Lynchings and the Economy: A Time-Series Reanalysis of Hovland and Sears (1940).' (1988) 55 Journal of Personality and Social Psychology 239-47.

Hewstone, M. J., Rubin, M. and Willis, H. E., 'Intergroup Bias.' (2002) 53 Annual Review of Psychology 575-604.

Hogg, M. A. and Vaughan, G. M., Social Psychology (6th edn, Pearson Education Limited 2011).

Hovland, C. I. and Sears, R. R., 'Minor Studies of Aggression: VI. Correlation of Lynchings with Economic Indices.' (1940) 9 The Journal of Psychology 301-10.

Jacobs, J. B. and Potter, K., Hate Crimes: Criminal Law and Identity Politics (Oxford University Press 1998). Jacobs, J. B. and Potter, K. A., 'Hate Crimes: A Critical Perspective.' (1997) 22 Crime and Justice 1-50. 
Kubrin, C. E. and Weitzer, R., 'New Directions in Social Disorganization Theory.' (2003) 40 Journal of Research in Crime and Delinquency 374-402.

Lyons, C. J., 'Community (Dis)Organization and Racially Motivated Crime.' (2007) 113 American Journal of Sociology 815-63.

Lyons, C. J., 'Defending Turf: Racial Demographics and Hate Crime Against Blacks and Whites.' (2008) 87 Social Forces 357-85.

McDevitt, J., Levin, J. and Bennett, S., 'Hate Crime Offenders: An Expanded Typology.' (2002) 58 Journal of Social Issues 303-17.

Medoff, H., 'Allocation of Time and Hateful Behavior: A Theoretical and Positive Analysis of Hate and Hate Crimes.' (1999) 58 The American Journal of Economics and Sociology 959-73.

Mills, C. E., Freilich, J. D., Chermak, S. M., Holt, T. J. and LaFree, G., 'Social Learning and Social Control in the Off- and Online Pathways to Hate Crime and Terrorist Violence.' (2019) Studies in Conflict \& Terrorism 1-29.

Morgan, G. and Poynting, S. (eds), Global Islamophobia: Muslims and Moral Panic in the West (Routledge 2016).

Müller, K. and Schwarz, C. 'Fanning the Flames of Hate: Social Media and Hate Crime' (2018) Journal of the European Economic Association.

Over, H. and McCall, C. 'Becoming Us and Them: Social Learning and Intergroup Bias.' (2018) 12 Social and Personality Psychology Compass e12384.

Perry, B., In the Name of Hate: Understanding Hate Crimes (Routledge 2001).

Poynting, S. 'What Caused the Cronulla Riot?' (2006) 48 Race \& Class 85-92.

Ray, L., Smith, D. and Wastell, L. 'Shame, Rage and Racist Violence.' (2004) 44 The British Journal of Criminology 350-68.

Relia, K., Li, Z., Cook, S. H. and Chunara, R., 'Race, Ethnicity and National Origin-Based Discrimination in Social Media and Hate Crimes across 100 U.S. Cities.' (2019) 13 (July) Proceedings of the International AAAI Conference on Web and Social Media 417-27.

Romarri, A., 'Do Far-Right Mayors Increase the Probability of Hate Crimes? Evidence From, Italy.' (August 31, 2020) accessed 12 August 2020.

Rothe, D. and Muzzatti, S., 'Enemies Everywhere: Terrorism, Moral Panic, and US Civil Society.' (2004) 12 Critical Criminology 327-50.

Ryan, M. E. and Leeson, P., 'Hate Groups and Hate Crime.' (2011) 31 International Review of Law and Economics 256-62.

Shafir, G., Meade, E. and Aceves, W. J. (eds), Lessons and Legacies of the War On Terror: From Moral Panic to Permanent War (Routledge 2013).

Sidanius, J. and Pratto, F., Social Dominance: An Intergroup Theory of Social Hierarchy and Oppression (Cambridge University Press 1999).

Stacey, M., Carbone-López, K. and Rosenfeld, R., 'Demographic Change and Ethnically Motivated Crime: The Impact of Immigration on Anti-Hispanic Hate Crime in the United States.' (2011) 27 Journal of Contemporary Criminal Justice 278-98.

Stephan, W. G. and Renfro, C. L., 'The Role of Threat in Intergroup Relations.' in Diane M. Mackie and Eliot R. Smith (eds), From Prejudice to Intergroup Emotions: Differentiated Reactions to Social Groups (Psychology Press 2002) 191-208.

Stephan, W. G. and White Stephan, C., 'Predicting Prejudice.' (1996) 20 International Journal of Intercultural Relations, Prejudice, Discrimination and Conflict 409-26. 
Sullivan, A. C., Ong, A. C. H., La Macchia, S. T. and Louis, W. R., 'The Impact of Unpunished Hate Crimes: When Derogating the Victim Extends into Derogating the Group.' (2016) 29 Social Justice Research 310-30.

Tajfel, H., 'Social Identity and Intergroup Behaviour' (1974) 2 Social Science Information 65-93.

Tolnay, S. E., Beck, E. M., Massey, J. L., 1989. The Power Threat Hypothesis and Black Lynching: 'Wither' the Evidence? Social Forces 67, 634-641.

Turpin-Petrosino, C., Understanding Hate Crimes: Acts, Motives, Offenders, Victims, and Justice (Routledge 2015).

Welch, M., Scapegoats of September 11th: Hate Crime and State Crimes in the War on Terror (Rutgers University Press 2006).

Whitley, B. E. , Jr, and Kite, M. E., Psychology of Prejudice and Discrimination $\left(^{\text {nd }}\right.$ edn, Wadsworth CENGAGE Learning 2010).

Woolf, L. M., and Hulsizer, M. R., 'Hate Groups for Dummies: How to Build a Successful Hate-Group.' (2004) 28 Humanity \& Society 40-62.

Open Access. This is an open-access article distributed under the terms of the Creative Commons Attribution 4.0 International License (https://creativecommons.org/licenses/by/4.0/), which permits unrestricted use, distribution, and reproduction in any medium, provided the original author and source are credited, a link to the CC License is provided, and changes - if any - are indicated. (SID_1) 